\title{
GUILFORD COUNTY SOLUTION TO THE OPIOID PROBLEM (GCSTOP): A MODEL FOR UNIVERSITYICOMMUNITY PARTNERSHIPS
}

\author{
STEPHEN J. SILLS*, CHASE N. HOLLEMAN, KENNETH J. GRUBER \\ *CHCS@UNCG.EDU; UNIVERSITY OF NORTH CAROLINA GREENSBORO, CENTER FOR HOUSING AND COMMUNITY \\ STUDIES, 1111 SPRING GARDEN STREET, GREENSBORO NC 27313
}

To cite this article: Sills, S. J., Holleman, C. N., \& Gruber, K. J. (2018). Guilford County Solution to the Opioid Problem (GCSTOP): A Model for University/Community Partnerships. Journal of Recovery Science, 1(2), c5. https://doi.org/10.31886/jors.12.2018.18

To link to this article: https://doi.org/10.31886/jors.12.2018.18

\begin{abstract}
There were over 700 overdoses and 180 deaths from opioids in Guilford County, NC in 2017. The Guilford Solution to the Opioid Problem (GSTOP) project leverages funds allocated by the STOP-Act to design, implement, and evaluate a rapid response program intended to decrease mortality from opioid overdoses. The program engages citizens who overdose in harm reduction practices, distributes naloxone kits to high-risk users, conducts community health education, coordinates community resources through the CURE Triad collaborative, and builds relationships focused on ending opioid overdose. This presentation will review the development of the partnership between Guilford County Emergency Medical Services and the University of North Carolina at Greensboro that has resulted in the GSTOP demonstration project. The presentation included background on the opioid epidemic in Guilford County, the development of CURE Triad (a community coalition to address overdoses) and the implementation of GSTOP, the unique features of hosting such a program within a university, the evaluation design, and preliminary outcomes of the program.
\end{abstract}

\section{HARNESSING STUDENT LEADERSHIP IN BUILDING A CENTER FOR STUDENTS IN RECOVERY AT A PRIVATE CATHOLIC UNIVERSITY IN CENTRAL TEXAS}

KARINA GIL*, REBECCA GOMEZ, DENNIS RUCKER, BEA BLACKMON, LYDIA C.
HAMNER, NOE GONZALEZ, ARMANDO SANCHEZ
*KEGIL@ollusa.edu; our LAdy of THE LAKE UNIVERSITY, 411 S.W. 24 TH St SAN ANTONIO, TX 78207

To cite this article: Gil, K., Gomez, R., Rucker, D., Blackmon, B., Hamner, L. C., Gonzalez, N., \& Sanchez, A. (2018). Harnessing Student Leadership in Building a Center for Students in Recovery at a Private Catholic University in Central Texas. Journal of Recovery Science, 1(2), c5. https://doi.org/10.31886/jors.12.2018.19

To link to this article: https://doi.org/10.31886/jors.12.2018.19

\section{ABSTRACT}

This presentation describes the different processes and steps taken by two faculty members from the social work department and a group of students to start a Center for Student Recovery (CSR) at a small private university in central Texas serving mostly first-generation Hispanic students. The presentation highlights the unique history of the university and how its mission and values align with the creation of a CSR, making it the first private catholic university with this type of service to its student population. Additionally, the presentation showcases the different stages undergone by the stakeholders to get to the point of student involvement. The stages include the social work department obtaining part of an SBIRT (Screening, Brief Intervention, and Referral to Treatment) grant which allowed for training to be embedded in certain classes which sparked conversations of substance and alcohol use among the student population. It also included a student health survey that provided a snapshot of the state of substance and alcohol use on campus, and the approval of a proposal presented to the University's board of trustee and president. Emphasis is given to the process of recruiting the student leadership, the student's motivation and their role in the creation of the CSR.

All authors approve this manuscript and the original submission. The authors report no conflicts of interest. This work is licensed under the CC-BY license. 